\title{
Synthesis of 9-substituted 9-deazaguanine derivatives
}

\author{
Alexandre F. Barbosa, Arlene G. Corrêa* \\ Departamento de Química, Universidade Federal de São Carlos, 13565-905, São Carlos, SP - Brazil \\ *Corresponding author.Tel: +16 33518281, e-mail: agcorrea@ufscar.br
}

Keywords: green chemistry, microwaves, deazaguanines, purine nucleoside phosphorylase

\section{INTRODUCTION}

Various derivatives of 9-substituted 9-deazaguanine and 9-deazahypoxanthine have been described as potent competitive inhibitors of purine nucleoside phosphorylase (PNP). ${ }^{1,2}$ In this work, we describe a greener method for the synthesis of 9deazaguanines employing microwaves (MW).

\section{RESULTS AND DISCUSSION}

Our synthetic strategy was based on the work described by Shih et al. ${ }^{3}$ (Scheme 1). Several procedures are described for the preparation of the starting material, 6-methyl-4-pyrimidinone derivatives 1, using guanidine or thiourea, ethyl acetoacetate, with or without base, under reflux of ethanol or methanol for several hours. ${ }^{4,5}$ Schmink et al. ${ }^{6}$ described recently a MW assisted synthesis of 6methylthiouracil (1b) using $\mathrm{KOH}$ in ethanol.

We tested the reaction for the preparation of 1a-c with and without base, solvent, under conventional heating and also under MW. The best results were obtained without base and solvent under MW irradiation in 65 and $56 \%$ yield, for $\mathbf{1 a}$ and $\mathbf{1 b}$, respectively (Scheme 1). 6-Methyluracil (1c) has not been obtained in any experimental condition we have tested.

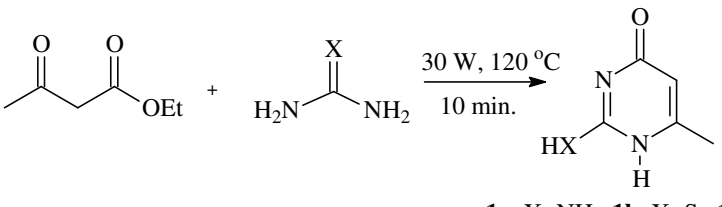

1a, $\mathrm{X}=\mathrm{NH} \quad \mathbf{1 b}, \mathrm{X}=\mathrm{S} \quad \mathbf{1 c}, \mathrm{X}=\mathrm{O}$

Scheme 1. Synthesis of 6-methyl-4-pyrimidinones.

The synthesis of 9-deazaguanines was then performed, by nitration of $\mathbf{1 a}$, followed by alkylation using $N, N$-dimethylformamide dimethyl acetal furnishing 3 . Reductive cyclization followed by microwave irradiation furnished 9-deazaguanine 4 in $90 \%$ yield. Under reflux for 2 h, 4 was obtained in only $61 \%$ yield. Friedel-Crafts aroylation using trifluoromethane sulfonic acid as catalyst, followed by the Wolff-Kishner reaction leads to the 9- substituted 9-deazaguanines 6 in low to moderate overall yield (Scheme 2 , Table 1 ). ${ }^{3}$

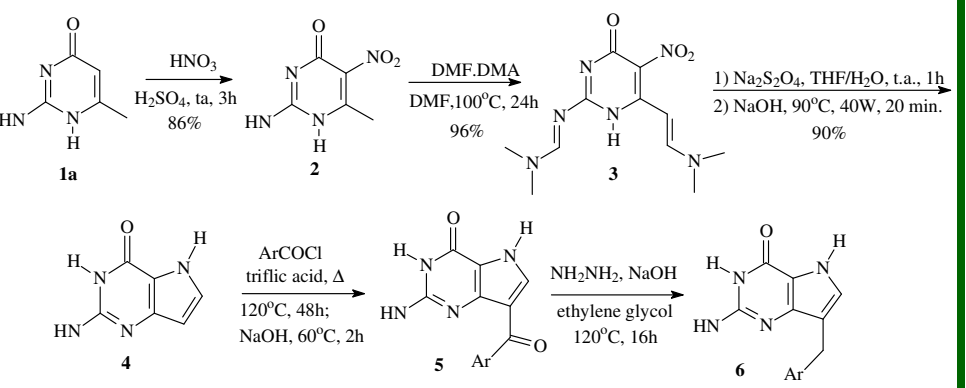

Scheme 1. Synthesis of 9-deazaguanines.

Table 1: Yields obtained in the synthesis of 6

\begin{tabular}{|c|c|c|}
\hline Benzoyl Chloride & 5, Yield (\%) & 6, Yield (\%) \\
\hline 4-chloro & 68 & 58 \\
\hline 4-bromo & 65 & 55 \\
\hline 3-fluor & 71 & 14 \\
\hline 3-chloro & 73 & - \\
\hline 3,4-dichloro & 75 & - \\
\hline 3-nitro & 68 & - \\
\hline 3,5-dichloro & 62 & - \\
\hline - & 53 & - \\
\hline 4-fluor & 64 & 16 \\
\hline 2,4,6-trichloro & 52 & - \\
\hline 2-chloro & 61 & 11 \\
\hline 4-iodo & 56 & 15 \\
\hline
\end{tabular}

\section{CONCLUSION}

New 9-substituted 9-deazaguanines were obtained employing MW in two steps of the synthetic route. These compounds are being evaluated against human and $S$. mansoni PNP enzymes.

\section{ACKNOWLEDGEMENTS}

FAPESP, CNPq and CAPES.

\section{REFERENCES}

${ }^{1}$ Balakrishnan, K.; et al. Blood 2006, 108, 2392.

${ }^{2}$ Castilho, M.S.; et al. Bioorg. Med. Chem. 2010, 18, 1421.

${ }^{3}$ Shih, H.; et al. Chem. Pharm. Bull, 2002, 50, 364-367.

${ }^{4}$ Foster, H. M.; Snyder, H. R. Org. Synth., Coll. Vol. 4, 638, 1963.

${ }^{5}$ Zhou, J.P. et al. Chin. Chem. Lett. 2008, 19, 669.

${ }^{6}$ Schmink, J. R. et al. Org. Proc. Res. Dev. 2010, 14, 205. 